\title{
Scenarios for the Equal Division of Paid and Unpaid Work in the Transition to Parenthood in Germany
}

\author{
Anna Dechant, Florian Schulz
}

\begin{abstract}
On the basis of a qualitative longitudinal study of 14 German couples, the conditions that are necessary and sufficient for an equal division of labour in the transition to parenthood are examined in an explorative way. Based on the assumption that couples with educational homogamy on a high level are probably more prone and sufficiently assertive to establish egalitarian relationships, we show that such arrangements cannot be sustained or achieved without the existence of specific contiguous conditions. A comparison of attitudes, family values and norms with actual everyday routines also suggests in many cases the well-known "verbal open-mindedness and rigid behaviour".
\end{abstract}

Keywords: Division of labour in the household · Transition to parenthood • Longitudinal study · Qualitative data · Germany

\section{Introduction}

The transition to first parenthood involves major changes to couples' everyday lives with consequences which can hardly be adequately assessed and planned for in advance. So far, the processes of decision making and coping with everyday life during this phase as well as the resulting longer-term consequences for couple's equal division of labour have rarely been analysed. Particularly for career-oriented and similarly (highly) educated couples the question arises how employment and family work can be shared in the transition to parenthood. Traditional gender roles, which generally assume complementary productivity by the partners, do not offer much orientation to such couples.

Although in opinion polls more and more people recently desire an equal division of labour (e.g. Lück 2009), this "verbal open-mindedness" continues to be contrasted in everyday life by a "rigid behaviour" (Beck/Beck-Gernsheim 1995: 20). For example, 45 percent of fathers would like to take parental leave (Institut für Demoskopie 2005: 11-12), yet under the conditions of the new parental leave regu- 
lations, only about 19 percent actually do so (Statistisches Bundesamt 2010: Table 1). Research on housework reveals a similar picture. Although at the beginning of intimate relationships housework is frequently shared equally, with increased relationship duration and in particular following the birth of the first child, however, responsibilities are shifted increasingly towards the women. Couples arranging the division of labour equally on a sustained basis are still relatively rare (cf. e.g. Schulz 2010). Hence, gender-specific division of labour is changing far more slowly than the corresponding attitudes. ${ }^{1}$

According to the egalitarian values model (van Berkel/de Graaf 1999), lasting egalitarian arrangements can be expected primarily among couples in which both partners have a high level of education and therefore, according to the assumption, have not only a similar degree of human capital, but are also rather open to liberal values and gender egalitarianism. Our qualitative empirical study focuses on 14 such couples in the transition to parenthood. In the following, we will at first discuss the theoretical expectations of the model in detail. It has become customary in the literature about the gendered division of labour to at least mention a variety of theories and mechanisms concerning the division of paid and unpaid work (e.g. Becker's human resource approach, different resource theories or the "doing gender" approach), because none of the established theories alone can comprehensively explain the division of paid and unpaid work in intimate relationships (Wengler et al. 2009). However, since we are not striving for a theory-testing analysis, but are exploratively seeking specific conditions underlying the observed arrangements, which for all intents and purposes go beyond the range of the established approaches, we deem the egalitarian values model as quite sufficient as a heuristic starting point for reconstructing the couple biographies.

In the first empirical step, we illuminate the individual components of the model, namely which educational constellations the couples exhibit, which attitudes the partners have, which types of division of labour they practised before, during and after the transition to parenthood and how individual normative beliefs and everyday routines are correlated.

Nonetheless, it appears that a high level of education and a greater open-mindedness towards democratic arrangements is merely a necessary and not yet a sufficient prerequisite for lastingly breaking down traditional structures if considering that tendencies of traditionalisation are also detectable in couples with educational homogamy on a high level (cf. Schulz 2010). In a second empirical step, we therefore examine which conditions lead to some couples resisting the traditionalising effect of the transition to parenthood with regard to the division of labour, while others are not able to do so. In this way, we gain indications of which conditions may be sufficient for a successful egalitarian division of labour.

1 We use the terms attitudes, values, orientations etc. following the suggestions that are going to be discussed in the editorial of the special issue to which this article will be assigned. 


\section{Theoretical considerations: The egalitarian values model}

Many empirical studies about the value change among women and men supply evidence that young couples are increasingly questioning traditional gender roles and developing egalitarian ideals of living together (e.g. Lück 2009). The question of which conditions are necessary in order to implement this normative change in actual everyday routines is investigated by van Berkel and de Graaf (1999) in their egalitarian values model using the division of housework as example.

The basis of their argumentation is the assumption that the education of the individuals can indicate specific values, attitudes and gender role orientations, as well as being interpreted as human capital. In the first case, van Berke/ and de Graaf (1999) anticipate a negative relation between the educational level and the time spent doing housework by men and women, since taking up household duties raises the opportunity costs of lost employment income. At the couple level, based on resource theoretical arguments this results in various constellations of which the theoretically most interesting is that of couples with educational homogamy. In these cases, the resource theories (cf. e.g. Blau 1964; Ott 1992) would predict an equal distribution of housework between the partners. In all other cases the division of labour is determined by the difference in the educational levels of the partners, whereby the partner with a higher level of education tends to do less housework (cf. Schulz 2010).

Another expectation with regard to the division of labour arises when considering the effect of the educational level as different support for values of equality and equity: "Whereas for the lower educated inequality between the sexes is given, the higher educated are aiming at gender equality in public and private spheres as much as possible" (van Berkel/de Graaf 1999: 790).

Against this background, van Berkel and de Graaf (1999) argue that an equal distribution of housework will not be achieved in all homogamous couples, but that the level of homogamy is also relevant. They only anticipate an egalitarian division of housework when both partners have a high level of education, since such couples are more inclined to pursue democratic values. These not only include tolerance, freedom and equality, but also gender-specific egalitarianism. By contrast, among couples with lower levels of education, traditional gender roles are continuously predominant. To support this argument, van Berkel and de Graaf (1999: 790) use empirical evidence from research on attitude and modernisation theory. It appears, for instance, that there is largely agreement in the literature on democratisation processes that a higher level of education is linked with greater approval for democratic values of equality and equity, which is also reflected in everyday actions. Also, modernisation theorists have pointed out that the educational expansion is one of the major factors determining the change of family and gender roles in western industrial nations. Besides the economical aspects associated with this, it also accounts for cultural changes with regard to once deeply rooted values and ideals (cf. e.g. also Lück 2009).

In their study for the Netherlands, van Berkel and de Graaf (1999) found empirical evidence for their considerations. Further indications in favour of the model 
are found in a Danish study by Bonke and Esping-Andersen (2011). Using time use data, they show that time used for childcare tends to be equally distributed among couples with educational homogamy on a high level, in particular because the men in these couples are considerably more involved than in couples with other educational constellations. They also interpret their finding stressing the significance of values and attitudes. A third indication that this specific couple constellation may stimulate greater gender equality in intimate relationships is provided by Greenstein (1996). Using US data, he shows that it is not enough if only one of the partners in a marriage pursues liberal gender role orientations to avoid traditional housework patterns. In his cross-sectional study, he reveals that the chances for turning away from traditional patterns in everyday life are the greatest if both partners have a "non-traditional" orientation (cf. also Künzler/Walter 2001: 195). Grasping education as an indicator for these "non-traditional" orientations, this interpretation corresponds to that of the egalitarian values model of van Berkel and de Graaf (1999). Finally, in his study of the division of housework in the course of marriages, Schulz (2010) finds empirical evidence in favour of the egalitarian values model for Western Germany.

Since it can be assumed that the relationship between educational level and approval of more egalitarian divisions of labour does not only apply to housework, but also to childcare and employment, we generalise the egalitarian values model in this manner. Hence, the working hypothesis for our qualitative empirical study is that the tendency of couples to fairly share employment and family tasks in the course of their relationship and specifically in the transition to parenthood is more pronounced among couples with educational homogamy on a high level; at the same time, these couples should show the lowest propensity to.

The discrepancies between the results of the attitude measurements and studies of actual everyday realities are, however, often obvious. Compared to couples with other educational compositions highly educated homogamous couples may exhibit an increased propensity to change their arrangement over the course of their relationships towards an equal division of labour or to retain such an arrangement; however this does not mean that they are basically able to resist tendencies to traditionalise. As the longitudinal study by Schulz (2010) on the division of housework shows, traditionalisation is the most frequent pattern among these couples, but to a lesser extent than among couples, for example, in which the man has a higher educational level than the woman. In the population average this leads to the continued dominance of the traditional division of labour among couples in Germany as in all other western industrial nations (cf. for Germany e.g. Huinink/Röhler 2005; Kühhirt 2011; Röhler/Huinink 2010; Schulz 2010; Wengler et al. 2009; international: e.g. Baxter et al. 2008; Kaufmann 2005; Schober 2011; Wiesmann 2010).

In a qualitative study of dual earner couples working in science, Schulte (2002) showed that a high level of education is not "automatically" accompanied by an equal division of labour. Buchebner-Ferstl and Rille-Pfeiffer (2008) demonstrate, also using qualitative interviews, how personal preferences concerning paid work and values play a role with regard to an equal division of childcare, while they are less explanatory for the division of housework. 
Against this background, we anticipate that a higher level of education paired with greater open-mindedness towards egalitarian arrangements is not a sufficient condition ensuring a lasting breakdown of traditional gender-specific structures in intimate relationships. In fact, the combination of circumstances in everyday life must also enable to practise an egalitarian division of labour. Therefore in this empirical study we search for the conditions that differentiate those couples who are successful in egalitarianism from those who pursue the traditional middle-class patterns concerning the gendered division of labour in the course of the transition to parenthood.

\section{Data and methods}

For the empirical study, we use data from a qualitative longitudinal study from the years 2006 and 2007 (Schulz et al. 2008). ${ }^{2}$ The aim of this study was to examine the division of labour in couples in the transition to their first parenthood. For this purpose, 14 couples were theoretically sampled (Glaser/Strauss 1998). They had to be cohabitating, childless and in the fourth to eighth months pregnant with their first child at the time of the first interview. Among all of these couples both partners were gainfully employed and had almost equal, in most cases high levels of educational resources. A second interview was held approximately six to twelve months following the birth of the child. Both partners were interviewed separately. The focus of the interviews was on the partners' distribution of employment, housework and childcare. All of these aspects were surveyed for the time of the interview as well as retro- and prospectively. The event-centred longitudinal design of the study allows examining the impact of the birth of the couple's first child on their division of labour.

The qualitative longitudinal design enables the comparison of the developments in the division of labour among couples with predominantly similar initial situations. According to the theoretical considerations in terms of the egalitarian values models it can be anticipated for people who are mostly educational homogamous on a high level that they practise an equal division of labour both prior to the birth of the child and continue to do so afterwards. Using the available data we can retrace the specific situations, expectations and rationales as well as the actual process of everyday routines among these specific couple constellations and determine the reasons for possible deviations from the model on the basis of concrete examples.

The interviews were analysed using a combination of approaches of qualitative content analysis as proposed by Mayring (2008), the construction of types according to individual cases as proposed by Kelle and Kluge (2010) and the confrontation

2 We thank the Deutsche Forschungsgemeinschaft and the Bayerische Staatsministerium für Arbeit und Sozialordnung, Familie und Frauen for financially supporting the data collection process as well as the analysis. The study is documented in detail in Schulz et al. (2008), in particular with regard to the sampling, the interview guidelines and socio-demographic information about those surveyed. 
of theory-guided hypotheses with qualitative data as proposed by Hopf (1993). In the qualitative content analysis, the relevant contents for the division of the different tasks are worked out from the interviews in a rule-based process. The themes of the interview manual serve as deductive categories, which are supplemented with aspects inductively gained from the data. This method condenses the contents of the single interviews (Mayring 2008). It is done for both interview times. Based on this summarising content analysis, each couple is examined as an individual case in order to illuminate the division of labour before and after the birth of the first child and ascertain and explain processes of change. In the next step, classificatory real types are formed from these individual cases (Kelle/Kluge 2010). Significant factors thereby are how the couples arrange their division of labour before and after the birth of their first child and which changes occurred in the transition to parenthood. Then, from the different behavioural patterns of the division of labour in the transition to parenthood, couples are deliberately chosen to identify the factors that lead to the different developments in the division of paid and unpaid work in the transition to first parenthood within the individual patterns. For the identification, as recommended by Hopf (1993), we always kept in mind our working hypothesis that egalitarian divisions can be expected to a greater degree among those couples we examined with educational homogamy on a high level. This hypothesis refers to singular facts and can therefore also be confirmed or rejected based on individual couples.

\section{Educational constellations in the sample}

Among 11 of the 14 interviewed couples, both partners have a similar educational degree; this is in ten cases a higher education entrance qualification (or an advanced technical college entrance qualification), in one case a secondary educational certificate. Among two couples, the woman has a higher level of education than her partner; the opposite is the case among one couple. In general, the respondents of the sample have an above-average high level of education, 23 of the 28 interviewees have a university-entrance diploma or technical diploma. Therefore this study is well suited for comparing and analysing the basic idea of the egalitarian values approach and the actual argumentation strategies of respondents with higher educational degrees, whether and to what extent these ideals are expressed and agree with the actual division of labour. We can also see whether the statements made and/or the actions change over the course of the birth.

Because we used a theoretical sampling, the couples are not a statistically representative random sample. This is emphasized by the attribute distributions of the respondents (Schulz et al. 2008), which differ considerably from figures that are representative of the population (e.g. higher average age of the women at their first child). However, it is not the aim of our study to provide quantitative certainties for the relations found, but instead to identify an empirical spectrum of possible scenarios for the division of labour in the transition to parenthood. In this respect we understand our interpretations in terms of "exemplary generalisations" (Wahl et al. 1982: 206; translated by the authors). 


\section{$4 \quad$ Empirical findings}

In the description of the empirical findings, we begin with the change of the division of labour in the transition to parenthood, then search for reasons for these processes and finally work out the conditions for egalitarian division of paid and unpaid work based on two exemplary cases.

\section{Division of labour before and after the birth of the child}

Table 1 shows that only 4 of the 25 possible combinations for the division of housework and employment are observable. Prior to the birth of the first child, almost half of the couples divide up housework in approximately equal parts. ${ }^{3}$ In the other cases, the women do the larger part of the housework than the men. The pattern with regard to employment reveals that among most of the couples both partners are employed to an approximately equal extent. In three cases, the man works longer hours than the woman, in one couple the opposite is the case. ${ }^{4}$

Tab. 1: Division of housework and employment before the birth of the first mutual child

\begin{tabular}{|c|c|c|c|c|c|c|}
\hline & & \multicolumn{5}{|c|}{ Division of housework } \\
\hline & & Man alone & Man > Woman & Man $=$ Woman & Man $<$ Woman & Woman alone \\
\hline \multirow{5}{*}{ 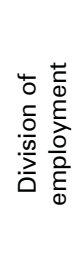 } & Man alone & & & & & \\
\hline & Man > Woman & & & & $B, D, H$ & \\
\hline & Man $=$ Woman & & & $A, C, F, G, K, N$ & I, J, L, M & \\
\hline & Man $<$ Woman & & & & E & \\
\hline & Woman alone & & & & & \\
\hline
\end{tabular}

Note: Categorization of the couples under the five categories is based essentially on the respondents' self-assessments, which were, however, validated using both partners' everyday histories that were reported independently of this explicitly requested information.

Source: own design

We label the couples who divide up both housework and employment equally $(A, C, F, G, K, N)$ as egalitarian, the couples in which the women do a larger share

3 In the following, housework is defined as all activities that arise in and around the home, in addition to cooking, cleaning, tidying up, shopping and similar, also such tasks as repairs, gardening and manual work. This broad definition of housework enables a comprehensive look at the entire work of reproduction in the domestic sphere independent of the gender-specific division of certain activities into so-called "female" or "male" activities.

4 Since gainful employment of both partners was a sample criterion, the case is excluded that only one of the partners is employed. 
of the housework and at the same time work the same (I, J, L, M) or lesser hours ( $B$, $D, H)$ than their partners are labelled as couples with partially specialised arrangements. Couple $\mathrm{E}$ can also be counted among this group since the man spends a lot of time working towards his professional further qualification, which in the narrower sense does not count as time for employment.

Table 2 shows how the couples divide up housework, employment and childcare following the transition to parenthood. Only two of the couples continue to share the housework in an equal manner $(\mathrm{C}, \mathrm{H})$. In all of the other cases, the women do most of or all of the housework. The distribution of employment has also changed: in 5 of the 14 couples, both partners work roughly the same hours. In the same number of couples the women work considerably fewer hours than the men. In another four cases only the men are employed or the women only work marginal hours.

Tab. 2: Division of housework, employment and childcare six to twelve months following the birth of the first mutual child

\begin{tabular}{|c|c|c|c|c|c|}
\hline & & \multicolumn{4}{|c|}{ Division of housework } \\
\hline & & Man $=$ Woman & \multicolumn{2}{|c|}{ Man $<$ Woman } & Woman alone \\
\hline \multirow{5}{*}{ 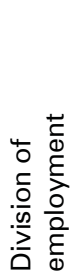 } & & \multicolumn{4}{|c|}{ Division of childcare } \\
\hline & & Man $=$ Woman & Man $<$ Woman & Woman alone & Woman alone \\
\hline & Man alone & & $D, L$ & G & $\mathrm{N}$ \\
\hline & Man > Woman & & $A, E, F, K, M$ & & \\
\hline & Man $=$ Woman & $\mathrm{C}, \mathrm{H}$ & $B, I$ & & $\mathrm{~J}$ \\
\hline
\end{tabular}

Note: See Tab. 1.

Source: own design

The birth of the first mutual child adds childcare as a new set of responsibilities to the couples' work duties. Only two of the couples share these duties equally; for the majority, childcare becomes the responsibility of the women. In our sample, at the time of the second interviews, none of the men takes on a greater share of the care of the child as their partners. Retrospectively, some couples report that the fathers took on a greater portion of childcare directly following the birth in order to relieve the women and allow them to recover from the delivery. However, this involvement was usually reduced by the men with the progressive convalescence of the women.

A more differentiated picture is seen following the transition to parenthood with regard to the combination of shares of housework, employment and childcare. Two couples divide up these spheres largely equally, whereby one of these couples practised a partially specialised arrangement prior to the birth. There are also couples with a partially specialised division of labour. Contrary to the situation before 
the birth of the first child, at the time of the second interview there are also couples who chose a highly specialised division of labour.

A descriptive look at the arrangements and the patterns (Fig. 1) illustrates that before the birth roughly half of the couples shared paid and unpaid work equally, however only one (couple $\mathrm{C}$ ) was able to retain this arrangement beyond the birth of the child. Another couple (H) shares the tasks at the time of the second interview equally, while beforehand it had a partially specialised division of housework and employment. Among the other couples we observed a (further) polarisation of responsibilities according to the traditional family model according to which the man is increasingly employed and the woman does the domestic chores.

Fig. 1: Patterns of the individual couples

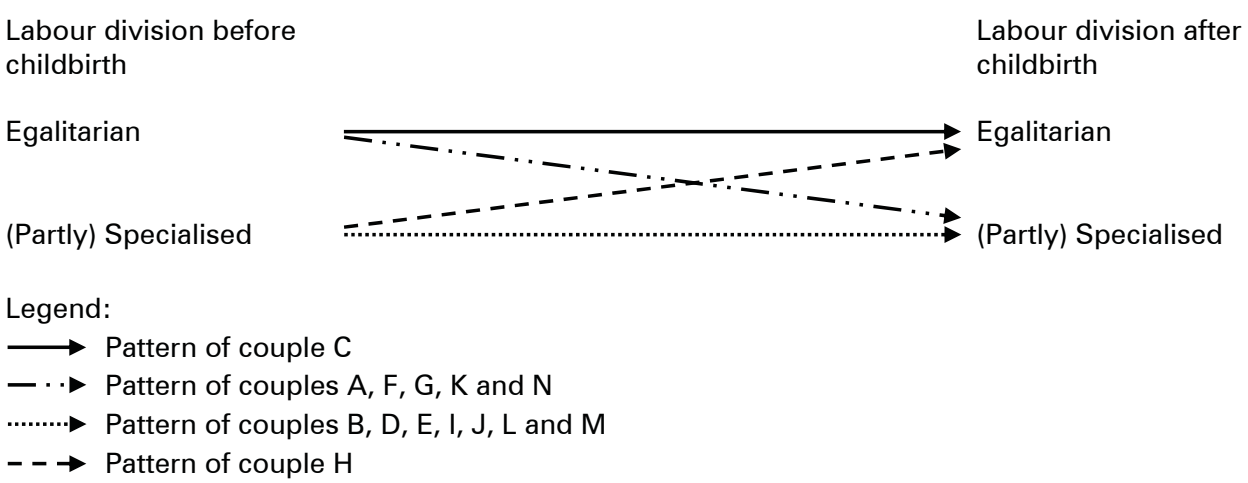

Source: own design

\section{Family values, family norms and the actual division of labour prior to the birth of the first child}

According to the egalitarian values model, nearly all of the couples in our sample should prefer and practise an arrangement of dividing labour equally. In this section, we compile the ideas expressed and the actual practice of the couples, in order to see which family values and norms were explicitly or implicitly communicated by the respondents and whether these concur with their actions.

All in all, the interviews contain many indications of the values of the couples interviewed. Largely all of the respondents refer to the egalitarian model. Dividing earning and family work equally between the partners appears to be a central and largely understood reference value for the couples. In addition, the couples differ in whether they strive for the equality ideal with or without conditions, or exclude it entirely for their actual situation and merely consider it a general frame of reference.

Prior to the birth, it was initially understood by all of the respondents that both partners have a paid work; this was not justified or questioned in the interviews by 
any of the individuals. ${ }^{5}$ This indicates that for childless couples with a similarly high level of education there is something like a dual earners norm that overrides the traditionally polarised gender roles ideal.

We also encounter this unquestioned ideal of equality with regard to the division of housework, in this case from the perspective of a man and practised by $\mathrm{G}$ and $\mathrm{K}$ :

"Basically, it's, it's fifty-fifty ... Yet it just worked out that way" (Int_K2: 246, 258). ${ }^{6}$

Other men argue,

"Yeah, it was ... clear to me in the first place that the household is not just ... women's work ... that's the way I was brought up, too, we always had to help out and that's the way it is there, too" (Int_L2: 127).

With a closer look at the arrangements practised by these couples, however, these expressed ideals prove to be more a case of "verbal open-mindedness," since "together" does not necessarily mean "the same amount". Only one of the men with this justification pattern (couple F) shares the housework with his partner equally, while the others (couples E, L) do a lesser share of the work than their female partners.

Men who detach themselves from the implicit egalitarian ideal and cite conditions for an egalitarian division of housework, tend to act to a greater degree according to their verbalised ideal. One example is the employment of both partners:

"it's clear from the start that..., if both go to work ... both also have to somehow do something" (Int_A2: 239).

The majority of those men who made such statements also practise an egalitarian arrangement in housework (couples A, C, N); only one of them does less than his partner (couple M). This can be interpreted in the sense of the bargaining theory (Ott 1992) but also available time (Coverman 1985) or the couple's ideals of fairness (Deutsch 1975).

5 At both interview times, all of the couples we directly asked for the reasons for the described division of labour in the two/three spheres. The statements are an initial indication of the response to the question of how the respective division came about. Since it is probable that the respondents are not aware of all of the reasons or they might not want to state some of them, throughout the entire interview additional or deviating explanations were sought.

6

The interview quotes are marked as follows: First it can be identified whether it was the first (Int) or the second interview (Int2), the ensuing letters indicate which couple it is with the respective identifying letters and which partner ( 1 for women and 2 for men) stated the quote. The paragraph numbers of the location of the text are documented after the colon. The paragraphs were numbered in sequence from top to bottom. "I" indicates passages by the interviewer. Passages by the respondent begin with " $\mathrm{R}$ ". Omissions are noted with three dots. All quotes are translated from the German originals which can be found in the Appendix as well as in the German original article (doi: 10.4232/10.CPoS-2013-06de, urn: urn:nbn:de:bib-cpos-2013-06de4). 
We encounter this conditioned ideal in its most acute form in rather resourceoriented rationales in Coverman's sense (1985):

"Just due to the fact that I work full-time and she works part-time she simply does ... the chores in the morning ... that come up and by the time I get home in the evening it's done, and that's why there's rather little for me to do" (Int_J2: 210).

This means whoever spends more time at their jobs has to spend less time doing housework, and only when both partners work the same hours, the housework should also be shared equally. All of the men who follow this pattern of argumentation do less household chores than their partners (couples $B, D, H, I, J$ ), even if both of them are employed almost identical hours (couples I, J).

We also encounter the unconditioned and conditioned justifications in the women's interviews, at first using the example of implicitness (practised this way by couples A, C, F, H; traditional-specialised deviation with couple L):

"I simply thought it was understood that if he's there anyway - even if he's not living here all the time - that he can do his part and that was also clear to him in the first place, because he's not the kind of guy who would sit back and let himself be taken care of ..., but that was also natural for him that he also ... would do household things" (Int_A1: 208).

However, the women more frequently express the conditioned ideal with regard to available time resources (cf. Coverman 1985):

"We do it over the weekend, too, J. [husband] does things sometimes, but I don't think it's all so necessary if I have time to get it done" (Int_J1: 594).

Most of the women who use this strategy of argumentation (couples $B, D, E, H, I$, J) do a greater share of the work than their partner. Couple $E$ is particularly remarkable in this respect, because although the woman works longer hours away from home she nonetheless spends more time doing housework in order to take the burden off her partner's shoulders since he is in further training. By contrast, couple $\mathrm{K}$ equally divides up the housework using these justification patterns.

One woman reports that the egalitarian division developed without any closer scrutiny:

"I: How did you share the work as first? Did you ever talk about it? ...

R: Actually, it usually just happened" (Int_N1: 223-229).

In only one case a woman, but none of the men, referred to the traditional image of the family (couple M), this couple is indeed best characterised by a traditional division of labour: 
"R: There was never any question about it. ... It was always understood that this [the housework] would be my responsibility." (Int_M1: 337-340).

This unquestioned adoption of the traditional woman's role fits into the logic of the egalitarian values model, since couple $M$ have less high educational levels. In this constellation the model does not assume an egalitarian, but a (partially) specialised division of labour.

Overall, with regard to the reasons given for the present division of labour there are a number of references to family values, principles and norms, which are also largely shared and cited by the partners in great agreement. For most of the respondents it is understood that employment and housework are shared by the couple. However, in practice this does not necessarily mean that they distribute the amount of work equally, even if the conditions cited for this, such as the repeatedly mentioned similar amount of paid working hours, are fulfilled. Hence, we already encounter indications that "verbal open-mindedness" and a high level of education of both partners are not sufficient to practise an egalitarian division of labour. In fact, it appears that additional factors play a role for this. Apart from egalitarian attitudes, frequent discussions about them are needed to ensure that patterns contradicting the expressed ideals do not inadvertently develop, as is reported by couple N. Additionally, different degrees of strain in gainful employment also appear to be balanced out in the domestic sphere, which leads to fairness in the total working time in the perception of the couples in the sense of the equity approach (cf. e.g. Deutsch 1975).

\section{Family values, family norms and the actual division of labour following the birth of the first child}

Which developments in the division of paid and unpaid work do the couples expect in the course of the transition to parenthood? Which changes to the current mutual responsibility for the spheres of employment and housework do the partners anticipate and how do they justify them? Which family values and norms are reflected in the expectations and realisations?

The anticipations for the first year following the birth of the child can be divided into four groups. We do not need to differentiate the expectations according to the respondent's sex, because in all of the couples both partners expressed very similar ideals. ${ }^{7}$ First, they expect a polar sharing of tasks following the birth of the child, whereby the man is largely responsible for earnings and the woman for housework

7 There are minor differences for example in couple J. The woman plans to return to work following the obligatory maternal leave, while the husband thinks she may take 6 months paternal leave. Since however over the short-term planning horizon of one year both have the same expectation, it is not necessary to differentiate between the statements of both respondents. Similarly minor deviations occur among other couples as well. However, both partners in all couples roughly refer to the same anticipations. 
and childcare (couples A, D, G, M, N). Most of the couples describe their decisionmaking process as a mutual deliberation that the woman initially wants to be there for the baby and therefore is interrupting her employment. As a consequence of the interruption, she will have more time at home and, due to this time and spatial proximity, can take over the housework. The women themselves make this argument, even if prior to the birth of the child they by no means accepted doing more housework than their partner based on conventional gender roles:

"so now in the future ... I'm at home and have the child, then it's understood that I will do most of the housework, simply because I'm at home, but if I'm also working, then I don't see why I should also do the household just because I'm a woman, not at all and he accepts it that way, too, ... that's actually totally obvious to both of us." (Int_A1: 54-55).

Some of the women wish to take parental leave on their own, exclude their partners from it, and do not want to relinquish this time at home with the baby. They very distinctly express the attitude that caring for the child is the woman's job:

"I: Did you ever consider deciding whether the man might take part of the parental leave?

R: Yes. ... for me that was not really an issue, because I like staying at home, ... but I think he ... wouldn't have had any qualms about being the house husband and staying at home, but just ... with regard to breastfeeding, there's no other way and I would not have allowed anybody to take that away from me to be quite honest." (Int_A1: 527-531).

The explicitness with which the traditionally middle-class family values are explained in the anticipations is not least surprising since, with only one exception, they did not play any role whatsoever in the justification for the division of employment and housework at the time of the first interview. Apparently the actors' values are influenced to such a degree by the specific situation of the transition to parenthood that previously unacceptable traditional patterns of organising everyday routines and cultural principles are considered feasible and desirable, even if they were clearly and distinctly rejected in the past. Many couples justify this change by referring to the biological rationale of breastfeeding. Nonetheless, it remains unclear whether such traditional arrangements can persist on a continuing basis.

Couples $B, F, I, J, K$ and $L$ make up the second group of anticipations. They anticipate a partially polar division, in which after a certain transitional period (which varies between the duration of maternity leave and a few months) with only the male being employed, both will again be employed, but the man to a greater extent. The woman will, however, spend more time on housework and childcare. As expressed in the quote above (Int_A1), the deviation from the previous ideal of equality is frequently justified using biological reasons.

Only couple E expresses the third type of expectations for their future division of labour. They assume that they will not achieve their ideal of an egalitarian division 
of labour and will instead live in a polar arrangement, in which the woman will work full time while the man will have irregular jobs and take over the larger share of the housework and childcare. The reason cited for this is that the man does not have a job for the time following the birth and is searching for employment, which makes the future difficult to plan.

We call the fourth type of anticipations egalitarian since these couples expect that both of them, after a brief initial period, will do about 50 percent of the work in all three spheres (couples $\mathrm{C}, \mathrm{H}$ ). Rejection of the traditional, middle-class pattern is, as van Berkel and de Graaf (1999) assume, important for the couples. As we describe further below in the specific case studies, here egalitarian values and attitudes encounter visions of how conditions can be used and created to also implement these ideals.

The comparison of anticipations with realisations (cf. Tab. 2) shows that for most couples wishes and reality coincide. Couples $B, E$ and $L$ were not able to implement their planned division of labour. In retrospect, this is accounted for in that the employment situation could not be realised as planned: the woman from couple B has a larger extent of employment due to a better business situation than expected, but is also dissatisfied that the child is cared for by an external caregiver to a greater extent than she wanted. Couple E experienced an entirely new situation, since prior to the birth the man had temporary employment contracts limited to a very short period of time and shortly following the birth was offered a permanent full-time position. He took advantage of this opportunity, whereby the woman decided to reduce her employment hours to care for the child, although this quite clearly contradicted the egalitarian values expressed by both in all three spheres. The self-employed, hourly work that the woman from couple $L$ had planned prior to the birth was not realised; neither she nor her man refer to this however in the second wave.

The following explanatory patterns emerge in a comparison of the rationales for the chosen arrangements at the time of the second interview. In addition to normative arguments, situational rationales are also cited here.

Couples $\mathrm{A}, \mathrm{G}$ and $\mathrm{N}$ explain their current arrangement at the second interview by the fact that the woman wished to care for the child and therefore interrupted her employment. Therefore, these women take up a far larger share of the childcare than their full-time employed partners. Both of the partners in these three couples derive from the fact that the woman spends more time at home that she must do most of the housework according to the middle-class traditional ideal. In addition, mainly the women argue according to Coverman (1985) and Deutsch (1975) that the family can spend quality time together when the man arrives home from work and he then does not have to do housework. Couple G hires a cleaner, so that this woman does less household tasks herself than the two others.

Among other couples, it is absolutely no question that both partners are and want to be employed. This corresponds to the logic of Ott (1992), whereby the own employment is considered something desirable. The women in couples $\mathrm{B}, \mathrm{E}, \mathrm{F}, \mathrm{I}, \mathrm{K}$ and $\mathrm{M}$ are, however, employed fewer hours than their partners. One of them (couple E) reduced her hours to allow her man to take on a full-time job. In this case, at least temporarily, his employment is given priority, which contradicts the ideal ex- 
pressed repeatedly by both of equally sharing all three spheres. This is justified with the specific situation that the man has a choice between full-time employment and unemployment. In this group, all of the women do more housework because they spend more time at home than the men and thus go along with the expectation of the man as well as the woman herself of doing a greater share of the routine chores (conditioned equality ideal). Nonetheless, all of the couples continue to expect that the man also takes on a certain share of the housework. Hence, the antenatal ideal of sharing the household work is not entirely abandoned, but adjusted to the situation. Some of the couples receive support from external service providers (couples $B$, I). In all of the cases the women do a greater share of the childcare, some of them can work from home and care for the child at the same time (couples B, I). All of the couples however procure support with childcare, whether from their own parents, day nurseries, babysitters or childminders.

One pattern of explaining the woman's (at least temporarily) dropping out of employment is the salary difference of the two partners and the couple's assessment that the man would probably lose social status at the workplace if he were to take parental leave. These are therefore economical (e.g. as defined by Becker 1998) as well as normative arguments, which can be associated with the rationale of the doing gender approach (cf. e.g. West/Zimmerman 1987). As with the above explanatory patterns, couples $\mathrm{D}, \mathrm{J}$ and $\mathrm{L}$ also justify the responsibility of the woman for the major share of the housework. While the woman in couple D works very few hours, the woman from couple $\mathrm{J}$ works a little more than part-time and the one from couple $L$ is not employed. The two former organise childcare during their working hours differently. In one case the child is cared for by the partner (couple D), while in the other case it is possible and practised to take the child along to work (couple $\mathrm{J}$ ).

In order to better understand the constellations of conditions and attitudes of the two couples who practise an egalitarian division of labour following the birth (couples $\mathrm{C}, \mathrm{H}$ ) and therefore correspond to the expectation of the egalitarian values approach, in the following we illuminate them in greater detail and sketch the differences between them and the couples who exhibit the pattern of a specialised division of paid and unpaid work.

\section{Case analysis of couple C}

Couple $\mathrm{C}$ differs from most of the other couples in that both partners are divorced, but both were still married at the time that they first met. The man must pay support to his ex-wife and the three children from their marriage. Both partners are university graduates in the field of business/engineering and work in the sales force or from home for the same company. For both, many overtime hours are part of their working routine. Both partners do housework, whereby the couple employs a cleaner who wipes and vacuums, cleans the bathroom and irons. The man took up the initiative for this. The couple either does the other household tasks, such as cooking, together or divides them up, for example grocery shopping. Each partner does about 50 percent of the household tasks that are not done by their external helper. 
Both partners consider it natural to share the housework. For the man, the employment of both partners is the decisive condition for his participation in the household:

"Well, if my partner were at home all day, it would surely be expected that she simply does certain things. When you get home in the evening, it's clear that certain things are already done. You'd probably be dissatisfied if they weren't. Since both of us are out all day, we're certainly also dissatisfied about certain things. ... But that's why you have to divide up the things equally and you don't have any right or reason to be dissatisfied if there's no food on the table in the evening. ... The only way to find a solution to that is to call first and ask 'What's for dinner? Did you make any plans yet?,' to make something yourself or to go out to eat." (Int_C2: 123).

This implicitness in the division of labour probably also leads to the couple only speaking very little about how the division actually came about and that they say the situation arose without question. They also do not express any opinions or attitudes about the division of labour in general or about gender roles, but the interviews implicitly contain them. The implicitness of the egalitarian division in particular indicates a greatly internalised ideal of equality as defined by the egalitarian values approach.

In light of the man's conditioned expectation of dividing housework equally, it can be assumed that he anticipates an unequal distribution for the time about the birth. This is as the woman will be out of the labour market since she plans to take parental leave after her maternal leave and to interrupt her employment for six months. However when asked about his expectations for the future, the man responds that nothing will change since the woman will probably be caring for the child a great deal. In this, his assessment differs from that of most of the other couples, who specifically state that since the woman will spend so much time within the household to care for the child, she will also do more housework.

"I: What do you expect then for the division of housework ..., once the baby ... has arrived? Do you anticipate ... shifts when the woman ... is home the first six months? ...

R: I don't think that anything will change. A. [name of partner] has to get used to the baby and to handling the baby first and will probably simply spend a lot of time caring for it." (Int_C2: 284-286).

It is very important for the woman to re-enter her job soon. On the one hand that is the only way she can continue to keep her present position and on the other hand she enjoys it and wants to avoid the role her mother took on, who stayed home at the request of her father. In this regard, her man's support obligations are a welcome rationale for substantiating her ideal of an egalitarian division of labour:

"What's important to me is that I am free to continue to work. S. (m) [name of the partner] has the charming advantage that he ... is liable for support and so he can't even think up the silly idea of saying 
'Honey, I have a great idea. You stay at home and I will afford it for you.' ... This saves me from that role like my mother has. As soon as I started school, my mother had to stay at home. This was really important to my father, too. When I told him we were expecting a baby, he simply assumed that I would stay at home in the future. ... 'Where'd you get that idea? You really want to work.' Yes. And then he blames it on S. Oh, yeah, S. can't do that. As if that was a negative thing. What's a benefit for me. Well, it's very important to me." (Int_C1: 364).

Fig. 2: Man's share of the work in couple C in the spheres of housework, employment and childcare over the course of time

in percent

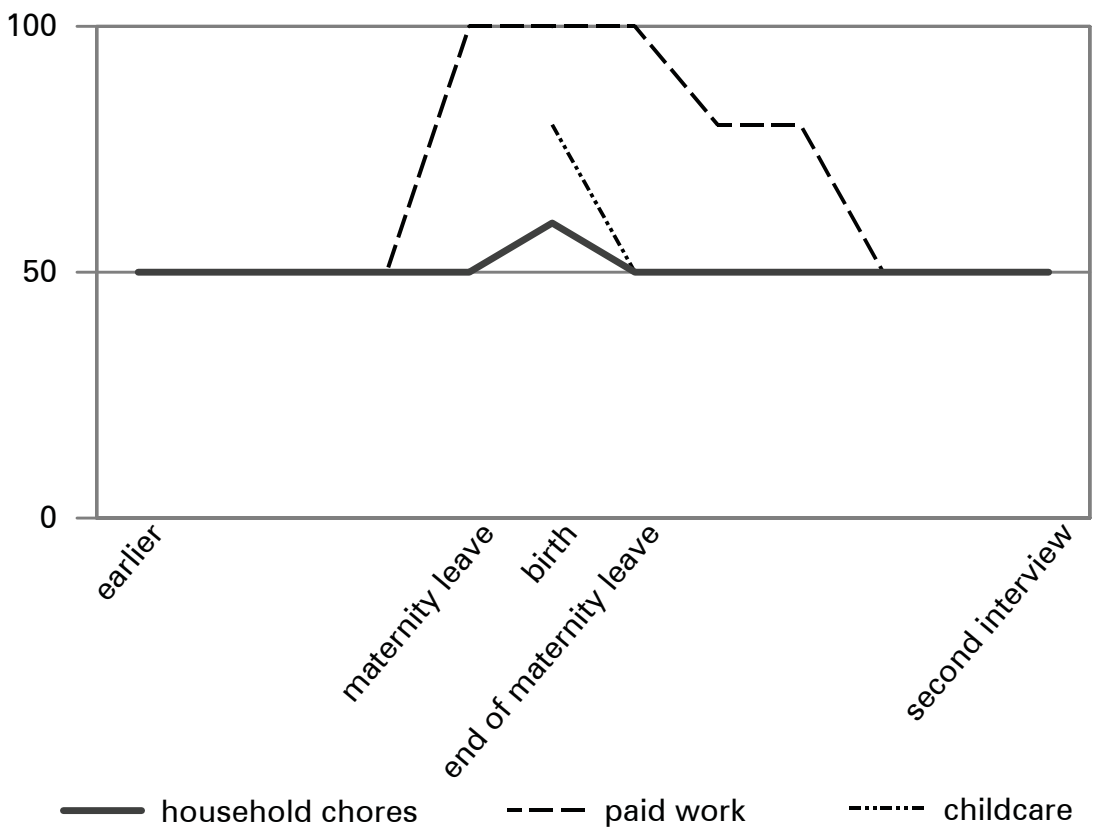

Note: The Y-axis shows the man's percentage in the work spheres of housework, employment and childcare. The time axis is subdivided by events that are relevant for the couple.

Source: own design

Figure 2 shows how the couple's division of labour changed over time. Before the pregnancy, the couple divided up the paid and unpaid work equally, as they did again at the time of the second interview. Shortly before and after the birth the man is temporarily the sole earner. The woman gradually re-enters her job and finally is working full time again. This is possible because a childminder cares for the child. Directly following the birth, the man did far more housework and a major share of 
the childcare in order to relieve the woman. Once she recovered from the delivery, the shares of both in housework and childcare levelled off at 50 percent, which is considered the normal level by the woman regardless of the fact that she did not work for a time or worked fewer hours than her partner:

"Well, let's say that when the baby was born of course he did more than I did. ... But simply due to the fact ... for a whole week I could hardly walk and after that only a little... But after that actually everything balanced back out to the normal level." (Int2_C1: 1892-1896).

In summary, both partners are convinced that housework should be done jointly. For the woman, the egalitarian division of labour is the normality, anything else is a deviation from this and caused by specific situations. For the man it is understood that he will share domestic chores with his partner after the birth in the same way as before the birth. Couple $C$ thus is exemplary for the egalitarian values model, which assumes that couples with similarly high levels of education have egalitarian attitudes and attempt to implement these attitudes in everyday routines. However, the couple's outsourcing is the sufficient condition for the equal division of chores. A major share of the work is outsourced to the cleaner and childminder so that the couple is able to divide up the remaining chores in an egalitarian manner. In the sphere of housework especially the unpopular chores and those that the man is unable (or unwilling, such as ironing) to do are outsourced. Another important condition for the egalitarian division of paid and unpaid work is the fact that both consider full-time employment normal. They are each able to work a number of days of the week from home and thereby can and want to care for the child at the same time. With regard to the childcare, it should be noted that the man also very actively demands that he can spend time with the child and sees himself as just as competent as his partner in all matters and strives to prove this by his behaviour.

\section{Case analysis of couple $H$}

The respondents are both academics; the woman majored in the social sciences, the man in the business-technical fields. At the time of the first interview, the woman works part-time and the man has a full-time position. Earlier both worked full-time, until the woman reduced her hours for health reasons. Both partners do housework. Many activities are assigned to one person in a relatively fixed way. The woman cooks, prepares the breakfast and irons, does the grocery shopping and administrative formalities. The man is responsible for dusting, making beds, purchasing beverages, carrying out the rubbish, repairing the car, filing the tax returns and washing the windows. Some activities are done by both, such as washing the dishes, filling and emptying the dishwasher, cleaning the bathroom, mopping and gardening. The woman tends to spend more time on housework, which both account for by the fact that she has fewer working hours and is at home longer hours than the man. Hence, when both were full-time employees the housework was shared equally, and the woman explains her greater share of housework with her fewer working hours, 
"because we both have the attitude that it's simply divided up and I simply happen to do a little more because I only work half days" (Int_H1: 158).

Although the woman attempts to finish many household tasks during the week so that the couple can spend a relaxed weekend together, it is clear that both partners must participate in the housework. The actual division of chores evolved primarily from preferences and skills.

For the time following the birth of the child, the couple intends for the woman to return to her job after the maternity leave. At the same time, the man will reduce his working hours to about 40 percent since he

"on his own ... had the ... desire, if a child then he wants to take care of it, too. ... yes, for him it was always that ... he actually wanted to do it from his own accord and ... based on our understanding of our roles in the relationship ... we have ... an emancipated perception" (Int_H1: 426).

Hence, following the birth the couple intends to equally divide up the labour amongst themselves. None of the other interviewed men express the willingness to reduce their working hours.

Figure 3 illustrates that the couple was able to implement these ideas in their everyday lives. Directly following the birth of the child, the man took on a large part of the childcare and considerably more housework. At that time only he was employed. When his wife's health improved, she increased her share of the housework. On her labour market re-entry, an arrangement solidified in which both do approximately 50 percent of all spheres of paid and unpaid labour.

Compared to earlier, the couple is attempting to outsource some household tasks since the birth of the child. The ironing is handed over to the woman's parents, a gardener does the gardening. Between the two interviews the couple has had a cleaner for a while,

$$
\text { "who now sadly - sadly for us - quit" (Int2_H2:286). }
$$

Both stress that they hope to get some relief from housework again. This is a change compared to the time of the first interview when the woman could not imagine this kind of outsourcing. It continues to be a matter of course for the couple to share the housework; the grown structures are not questioned. Sometimes they agree on who will do what work, whereby it is usually a question of who will take care of the child and who will do housework:

"But it's often like, let's say, the washing machine needs to be emptied or the dishwasher, do you want to do it or do you want to watch the baby? He always rather says he wants to watch the baby." (Int2_ H1: 788).

It is of prime importance for the couple's division of labour that both of them can care for the child and are employed: 
"for us it was always the optimal arrangement: Both work and both take care of the baby" (Int2_H1: 388).

Fig. 3: Man's share of the work in couple $\mathrm{H}$ in the spheres of housework, employment and childcare over the course of time

in percent

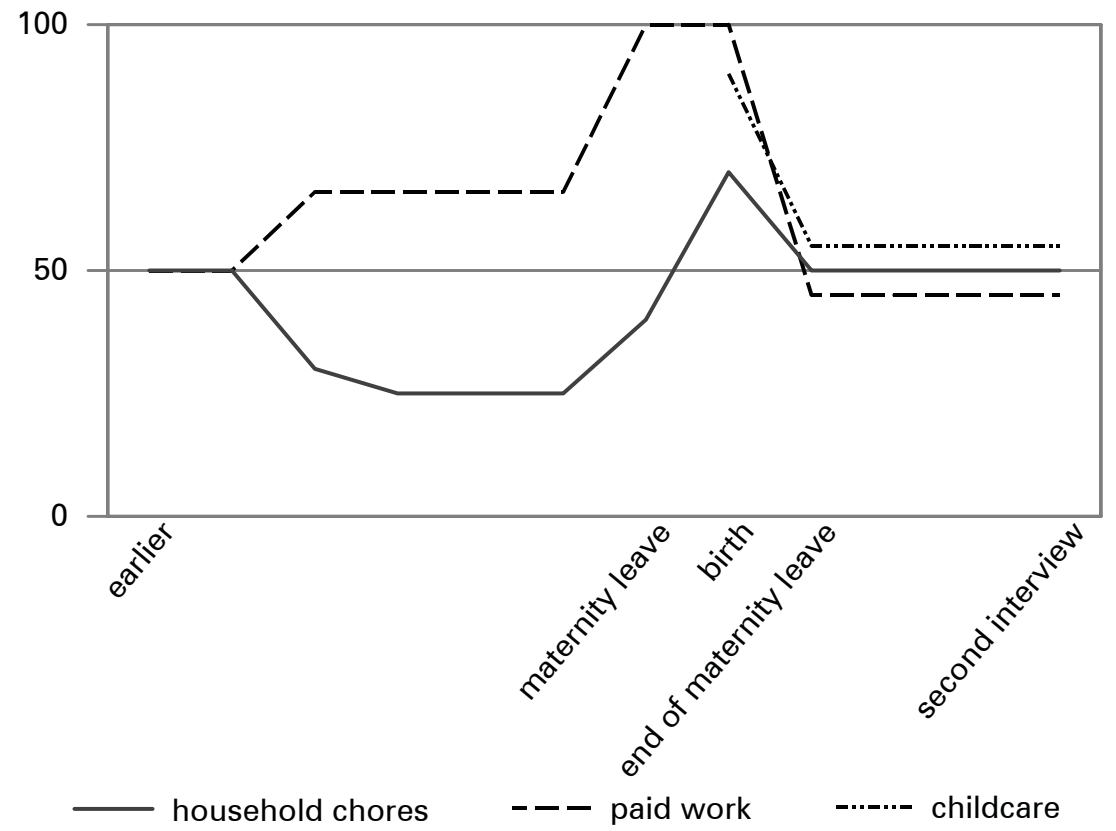

Note: See figure 2.

Source: own design

This is also the ideal situation for the man. It may be that this assessment was influenced by the fact that the woman may not have wanted to have a baby if the man had not reduced his working hours:

"I have to say, though, if my husband had said he didn't want that....

I don't know if I would have wanted to have a baby, the idea of spending the whole week at home with the baby and nothing else ... would have been, I think, not really my thing." (Int2_H1: 261).

Although couple $\mathrm{H}$ explicitly expresses the preference that the arising work should be equally allocated to the partners, an egalitarian division of housework is not essential for every situation. Particularly in the time following the birth the approximately equal distribution of the household tasks arose from the desire of both that the father also participates in childcare and that the woman not only cares for the child, but that both are employed part time in order to attain these objectives. Hence, the egalitarian division of housework appears more like a by-product 
of the egalitarian division of the other two spheres although both partners are highly sensitised to this subject and explicitly wish for the equal distribution of work, especially in the sphere of childcare (this was expressed otherwise only by couples $\mathrm{C}$ and $\mathrm{E}$ ). In order to keep the amount of housework as low as possible, the couple procures external help and aims to expand that in the future.

\section{Conditions enabling an equal division of paid and unpaid work}

In most of the interviewed couples and thus even among highly educated and homogamous couples, we find a specialised division of labour in which the man does a greater share of paid work and the woman is primarily responsible for housework and childcare in the first year following the birth. This pattern is not in accordance with the egalitarian values model, as it assumes that couples in which both partners have a high level of education tend to exhibit more democratic attitudes and thus strive for an egalitarian division of labour in all spheres and wish to continue to do so beyond the birth of the first child.

Therefore, the question arises how the couples that share paid and unpaid work equally after the transition to parenthood differ from those couples that pursue a rather specialised arrangement. As described above, the egalitarian division of all three spheres of labour after the transition to parenthood is only observed in couples $\mathrm{C}$ and $\mathrm{H}$.

At first, it is conspicuous that couple $\mathrm{H}$ did only practise an egalitarian division of labour at the time of the second interview and prior to the birth had an arrangement in which the man had more working hours and participated less in the housework. The different time spent for employment was given as the explanation for the partially specialised arrangement, which both partners actually rather disapprove. That is why this couple very frequently discussed its ideas about how to organise everyday life in the transition to parenthood. The man argued that he would like to take up his fair share of the childcare and thus would reduce his working hours. This matched the attitude of the woman who wholeheartedly rejects a traditionally specialised division of paid and unpaid work and was unsure whether she would have wanted to have a child without her man's willingness to be involved in childcare (this can be understood as a negotiation over the division of labour). The egalitarian arrangement following the birth consequently was the result of strong ideals and values of gender equality, reminding of van Berke/ and de Graaf's (1999) model. This is coupled with the man's opportunity to reduce his working hours, which is easily possible at his workplace and is further supported by his low career ambition. In order to realise the ideals, the couple additionally takes advantage of many options for outsourcing household tasks. This is consistent with the desire to spend as much time as possible with the child and to organise the other spheres in a way enabling this. Couple $\mathrm{H}$ thus pursues a combination of the management strategies described by Rüling (2007) to circumvent "the traps of traditionalisation".

By contrast, couple $C$ divides the spheres of housework and employment equally both before and after the birth of the child. For both partners it is clear to share the 
housework equally if both are working the same hours. Full-time employment is not questioned by either of them, for it is an important factor of their self-concept. The amount of domestic work that needs to be done by the couple is minimised as much as possible: the couple has a cleaner and often eats out. Since her own employment is very important to the woman and she can only keep her position if she returns to work quickly and the man is obliged to support his children from his first marriage, the couple decides that after a brief interruption the woman will pursue her job full time again. She re-enters in two stages. While she is at home the man does at least 50 percent of the housework and childcare. Following van Berkel and de Graaf's (1999) idea, it is a matter of course for him to continue to do household work to the same extent. He also wants to care for his child and tells his partner so. Even after the birth the couple pursues a strategy of extensively outsourcing. In addition to housework, this also applies to childcare. The couple has a childminder who takes care of the child three days of the week, while they take care of the child on the other days. It is crucial for this possibility that both respondents can work from home two days of the week and can allocate their time freely. In addition to egalitarian values regarding the division of labour, this couple also exhibits a strong orientation towards employment. Unlike couple $\mathrm{H}$ both are working full-time six months after the birth and structure their everyday life using every possibility to outsource tasks so that employment, housework and childcare can be divided up equally between both respondents.

\section{$5 \quad$ Conclusions}

Our study contributes to understanding the division of paid and unpaid work in couple's households in the transition to parenthood. Based on qualitative longitudinal data, we analysed first which arrangements couples practise before and after the birth of their first child and second how these patterns can be evaluated against the background of the societal rhetoric of gender equality as well as the couples' attitudes, principles and rationales. We considered all three spheres, employment, housework and childcare, jointly. We did not presume specific causalities a priori (which would be reflected in the quantitative case in the definition of dependent and independent variables), but reconstructed the conditions for an egalitarian arrangement from the couples' perspectives. This made it possible to separate necessary and sufficient conditions for an equal division of paid and unpaid work.

The analyses showed that the studied couples with educational homogamy on a high level express egalitarian values, such as those supposed by the egalitarian values model. Nonetheless not all of the couples are able to implement these attitudes in their real division of paid and unpaid work and retain it beyond the transition to first parenthood. Hence, it seems that even if egalitarian values are prevalent, special concomitant circumstances are necessary to transfer the convictions into action, such as the possibility of reducing the working hours or to do a large part of the paid work from home. As the example of couple E shows, the lacking option to reduce the working hours can render an egalitarian division impossible if the part- 
ners wish to care on their own for the child as much as possible. If the willingness is given to use external caregivers for a baby under the age of one year, a reduction of employment hours seems not to be a necessary condition, as the example of couple $\mathrm{C}$ shows. Hence, outsourcing work is one determining factor influencing the egalitarian division of housework and childcare in a positive manner. It requires, in turn, a sufficiently high income as well as specific attitudes, values and principles, such as a low career ambition of the man (e.g. couple H), the man's strong desire to care for the child equally (e.g. couples $\mathrm{C}, \mathrm{H}$ ) or a fundamental awareness of the issue and frequent discussion about the division of labour (e.g. couples $\mathrm{C}, \mathrm{H}){ }^{8}$

All in all, our study illustrates that the division of labour in intimate relationships must be studied with far more differentiation than is often the case. In particular, it is very important to review different spheres of labour together. It must be taken into consideration that the division of labour in the different spheres follows different rationales: the division of childcare is often decided upon the basis of preferences or gender-specific identities; especially in the initial period following the birth breastfeeding is also an important criterion; many women report a certain social pressure in this respect (cf. e.g. Ehnis 2008 on the importance of breastfeeding). Decisions about the employment situation are based on the one hand on the decision about childcare and on the other hand on the fact that a certain amount of material prosperity should be attained. Sometimes, the gender-specific perceptions and assumptions of sanctions for an interruption or reduction of employment are important for the decisions; this is in particular the case as employment is a crucial component of the male gender role (cf. Baur/Luedtke 2008). By contrast, hardly any of the couples appears to make decisions about housework explicitly and prospectively, and this precisely appears to reduce the chances for an egalitarian division of labour. In many cases, well-known behavioural patterns are first adopted to such an extent that the women take up an increasingly greater share of the chores. From the couples' points of view, these inequalities are quite reasonable during the studied phase (cf. Kaufmann 2005), as they are meaningful and relieve the couples from further negotiations. Meanwhile, it seems that hardly any of the actors is aware that in doing so social structures that regulate the everyday routines are concurrently reproduced in the form of (mostly irreversible) institutions (cf. Schulz 2010). Hence, learning more about the processes of rationalisation and life planning of couples in the transition to parenthood is a way to unravel the phenomenon of the "traditional division of labour" which - although rejected verbally by most people - is nonetheless still practised in line with existing societal structures. It seems that an egalitarian division of paid and unpaid work is hardly realisable unless the mechanisms of traditionalisation in couples are uncovered and discussed in detail and constructively, both in the field of (social) sciences and in couples' everyday lives.

8 In the scope of this study, it is not possible to check whether the conditions cited by the couples who exhibit a (partially) specialised division of labour following the birth were not producible or not desired. This was the result of a review of the interview material. 


\section{References}

Baur, Nina; Luedtke, Jens 2008: Männlichkeit und Erwerbsarbeit bei westdeutschen Männern. In: Baur, Nina; Luedtke, Jens (Hrsg.): Die soziale Konstruktion von Männlichkeit. Hegemoniale und marginalisierte Männlichkeiten in Deutschland. Opladen: Budrich: 81-103.

Baxter, Janeen; Hewitt, Belinda; Haynes, Michele 2008: Life course transitions and housework: Marriage, parenthood, and time on housework. In: Journal of Marriage and Family 70,2: 259-272 [doi: 10.1111/j.1741-3737.2008.00479.x].

Beck, Ulrich; Beck-Gernsheim, Elisabeth 1995: The Normal Chaos of Love. Cambridge: Polity Press.

Becker, Gary S. 1998: A Treatise on the Family. $4^{\text {th }}$ edition. Cambridge: Harvard University Press.

Blau, Peter M. 1964: Exchange and Power in Social Life. New York: Wiley.

Bonke, Jens; Esping-Andersen, Gøsta 2011: Family investments in children. Productivities, preferences, and parental child care. In: European Sociological Review 27,1: 43-55 [doi: 10.1093/esr/jcp054].

Buchebner-Ferstl, Sabine; Rille-Pfeiffer, Christiane 2008: Hausarbeit in Partnerschaften. Studie „The glass partitioning wall“ zur innerfamilialen Arbeitsteilung - Ergebnisse für Österreich. OIF-Working Paper 69. Wien [URL: http://www.oif.ac.at/fileadmin/OEIF/ workingaper/wp_69_hausarbeit.pdf, 12.03.2012].

Coverman, Shelley 1985: Explaining husband's participation in domestic labor. In: Sociology Quarterly 26,1: 81-97 [doi: 10.1111/j.1533-8525.1985.tb00217.x].

Deutsch, Morton 1975: Equity, equality, and need: What determines which value will be used as the basis of distributive justice? In: Journal of Social Issues 31,3: 137-149 [doi: 10.1111/j.1540-4560.1975.tb01000.x].

Ehnis, Patrick 2008: Hegemoniale Mütterlichkeit. Vom selbstverständlichen Einverständnis in die gesellschaftstypische Arbeitsteilung nach der Geburt eines Kindes. In: Marburger Gender-Kolleg (Hrsg.): Geschlecht Macht Arbeit. Interdisziplinäre Perspektiven und politische Intervention. Münster: Westfälisches Dampfboot: 56-69.

Glaser, Barney G.; Strauss, Anselm L. 1998: Grounded Theory. Strategien qualitativer Forschung. Bern: Huber.

Greenstein, Theodore N. 1996: Husbands' participation in domestic labor. Interactive effects of wives' and husbands' gender ideologies. In: Journal of Marriage and Family 58,3: 585-595 [URL: http://www.jstor.org/stable/353719, 12.03.2012].

Hopf, Christe/ 1993: Fragen der Hypothesenbildung und Hypothesenprüfung. In: Hopf, Christel; Schmidt, Christiane (Hrsg.): Zum Verhältnis von innerfamilialen sozialen Erfahrungen, Persönlichkeitsentwicklung und politischen Orientierungen. Dokumentation und Erörterung des methodischen Vorgehens in einer Studie zu diesem Thema. Hildesheim: 13-17 [URL: http://w2.wa.uni-hannover.de/mes/berichte/rex93.htm, 12.03.2012]

Huinink, Johannes; Röhler, Heiko K. A. 2005: Liebe und Arbeit in Paarbeziehungen. Zur Erklärung geschlechtstypischer Arbeitsteilung in nichtehelichen und ehelichen Lebensgemeinschaften. Würzburg: Ergon.

Institut für Demoskopie 2005: Einstellungen junger Männer zu Elternzeit, Elterngeld und Familienfreundlichkeit im Betrieb. Ergebnisse einer repräsentativen Bevölkerungsumfrage. Allensbach [URL: http://www.uni-tuebingen.de/frauenvertreterin/download/ allensbach-vaeter.pdf, 16.08.2011]. 
Kaufmann, Jean-Claude 2005: Schmutzige Wäsche. Ein ungewöhnlicher Blick auf gewöhnliche Paarbeziehungen. $2^{\text {nd }}$ edition. Konstanz: UVK.

Kelle, Udo; Kluge, Susann 2010: Vom Einzelfall zum Typus. Fallvergleich und Fallkontrastierung in der qualitativen Sozialforschung. $2^{\text {nd }}$ edition. Wiesbaden: VS.

Kühhirt, Michael 2012: Childbirth and the long-term division of labour within couples: How do substitution, bargaining power, and norms affect parents' time allocation in West Germany? In: European Sociological Review 28,5; 565-582 [doi: 10.1093/esr/ jcr026].

Künzler, Jan; Walter, Wolfgang 2001: Arbeitsteilung in Partnerschaften. Theoretische Ansätze und empirische Befunde. In: Huinink, Johannes; Strohmeier, Klaus Peter; Wagner, Michael (Hrsg.): Solidarität in Partnerschaft und Familie. Zum Stand familiensoziologischer Theoriebildung. Würzburg: Ergon: 185-218.

Lück, Detlev 2009: Der zögernde Abschied vom Patriarchat. Der Wandel von Geschlechterrollen im internationalen Vergleich. Berlin: edition sigma.

Mayring, Philipp 2008: Qualitative Inhaltsanalyse. Grundlagen und Techniken. $10^{\text {th }}$ edition. Weinheim: Beltz.

Ott, Notburga 1992: Intrafamily Bargaining and Household Decisions. Berlin: Springer.

Röhler, Heiko K. A.; Huinink, Johannes 2010: Pair relationships and housework. In: Treas, Judith; Drobnic, Sonja (Hrsg.): Dividing the Domestic. Men, Women, and Household Work in Cross-National Perspective. Stanford: University Press: 192-213.

Rüling, Anneli 2007: Jenseits der Traditionalisierungsfallen. Wie Eltern sich Familienund Erwerbsarbeit teilen. Frankfurt/Main: Campus.

Schober, Pia S. 2013: The parenthood effect on gender inequality: Explaining the change in paid and domestic work when British couples become parents. In: European Sociological Review 29,1: 47-85 [doi: 10.1093/esr/jcr041].

Schulte, Jürgen 2002: Dual-career couples. Strukturuntersuchung einer Partnerschaftsform im Spiegelbild beruflicher Anforderungen. Opladen: Leske+Budrich.

Schulz, Florian 2010: Verbundene Lebensläufe. Partnerwahl und Arbeitsteilung zwischen neuen Ressourcenverhältnissen und traditionellen Geschlechterrollen. Wiesbaden: VS.

Schulz, Florian; Jabsen, Annika; Rost, Harald 2008: Zwischen Wunsch und Wirklichkeit - Der Alltag erwerbsorientierter Paare beim Übergang zur Elternschaft. Methodenbericht einer qualitativen Längsschnittstudie. ifb-Materialien 4/2008. Bamberg [URN: urn:nbn:de:0168-ssoar-125388].

Statistisches Bundesamt 2010: Öffentliche Sozialleistungen. Statistik zum Elterngeld. Gemeldete beendete Leistungsbezüge 2009. Wiesbaden.

van Berkel, Michel; de Graaf, Nan Dirk 1999: By virtue of pleasantness? Housework and the effects of education revisited. In: Sociology 33,4: 785-808 [doi: 10.1177/ S0038038599000498].

Wahl, Klaus; Honig, Michael S.; Gravenhorst, Lerke 1982: Wissenschaftlichkeit und Interessen. Zur Herstellung subjektivitätsorientierter Sozialforschung. Frankfurt/Main: Suhrkamp.

Wengler, Annelene; Trappe, Heike; Schmitt, Christian 2009: Alles wie gehabt? Zur Aufteilung von Hausarbeit und Elternaufgaben in Partnerschaften. In: Zeitschrift für Bevölkerungswissenschaft 34,1-2: 57-78 [doi: 10.1007/s12523-010-0033-2]. 
Wiesmann, Stephanie 2010: 24/7 Negotiation in Couples' Transition to Parenthood. ICS Dissertation Series, Issue 167. Universiteit Utrecht [URL: http://igitur-archive.library. uu.nl/disse rtations/2010-0909-200252/UUindex.html, 12.03.2012].

West, Candace; Zimmerman, Don 1987: Doing gender. In: Gender and Society 1,2: 125-151 [doi: 10.1177/0891243287001002002].

Translated from the original text by the Federal Institute for Population Research, for information only. The reviewed and authors' authorised original article in German is available under the title "Bedingungsszenarien einer partnerschaftlichen Arbeitsteilung beim Übergang zur Elternschaft in Deutschland", DOI 10.4232/10.CPoS-2013-06de or URN urn:nbn:de:bib-cpos-2013-06de4, at http:// www.comparativepopulationstudies.de.

Date of submission: 01.02.2011

Date of Acceptance: 15.08 .2012

Dipl.-Soz. Anna Dechant ( $\varangle$ ). State Institute for Family Research at the University of Bamberg. Germany. E-Mail: anna.dechant@ifb.uni-bamberg.de URL: http://www.ifb.bayern.de/mitarbeiter/dechant.html

Dr. Florian Schulz. University Erlangen-Nürnberg, Central University Administration. Germany. E-Mail: florian.schulz@fau.de URL: http://www.fau.de 


\section{Appendix}

\section{Original German Interviews}

(a) "im Prinzip ist es, ist es eine Fifty-Fifty-Aufteilung ... Hat sich aber einfach so ergeben"

(b) „Ja, das war für mich schon ... von vornherein klar, dass der Haushalt nicht allein ... bei der Frau ist ... ich kenne es von daheim auch, wir haben auch immer mithelfen müssen, und genauso ist es halt da auch"

(c) „das wird einem schon von vornherein klar, dass man dann ..., wenn beide auf Arbeit gehen, ... auch beide irgendwie was machen müssen"

(d) "Einfach dadurch, dass ich ganztags arbeite und sie halbtags arbeitet, macht sie einfach ... am Vormittag die Arbeiten, ... die so anfallen, bis ich abends komme, ist es erledigt, deswegen fällt da eigentlich für mich wenig an"

(e) "Ich habe es halt selbstverständlich gefunden, wenn er sowieso da ist, auch wenn er jetzt nicht fest da wohnt, dass er seinen Teil halt dann mit dazu beitragen kann und das war ihm eigentlich auch von vornherein klar, weil er ist nicht so ein Typ, der sich dann ins gemachte Nest setzt ..., sondern das war dann für ihn auch selbstverständlich, dass er dann auch ... Haushaltssachen macht"

(f) "wir machen auch am Wochenende, der J. [Ehemann] macht schon mal was, aber ich finde das auch nicht so notwendig, wenn ich die nötige Zeit dafür habe, das zu machen"

(g) "I: wie habt ihr euch zunächst die Aufgaben geteilt? Habt ihr das dann irgendwie besprochen?...

B: Das hat sich eigentlich meistens so ergeben"

(h) "B: Das stand nie zur Frage. .... Also da war eigentlich immer schon klar, dass das [die Hausarbeit] mein Aufgabenbereich wird."

(i) „jetzt dann in Zukunft ... ich bin daheim und habe das Kind, dann ist es schon klar, dass ich dann den Großteil des Haushalts mache, weil ich einfach daheim bin, aber wenn ich gleichzeitig arbeite, dann sehe ich das nicht ein, dass ich dann auch noch den Haushalt machen soll, nur weil ich eine Frau bin, also gar nicht und das sieht er auch ein, ... das ist auch völlig klar eigentlich zwischen uns." 
(j) "I: Hat das bei Ihnen mal angestanden diese Entscheidung, ob der Mann einen Teil der Elternzeit nimmt?

B: Ja. ... von mir aus war das eigentlich kein Thema, weil ich gerne daheim bleibe, ... aber ich denke er ... hätte überhaupt kein Problem damit, Hausmann zu sein und daheim zu bleiben, aber schon allein, ... was das Stillen angeht, geht es ja gar nicht anders und ich hätte mir das auch nicht nehmen lassen, muss ich ganz ehrlich sagen."

(k) „Wenn jetzt meine Lebensgefährtin den ganzen Tag zuhause wäre, würde man sicherlich erwarten, dass sie gewisse Dinge einfach erledigt. Wenn man abends heimkommt, dass dann gewisse Dinge gemacht sind, das ist ja wohl klar. Man wäre dann wahrscheinlich unzufrieden, wenn es nicht so wäre. Dadurch dass wir beide den ganzen Tag unterwegs sind, ist man sicher auch über viele Dinge unzufrieden. ... Aber deswegen muss man sich die Dinge gleichmäßig teilen und hat gar keine Berechtigung oder keinen Grund, abends unzufrieden zu sein, wenn abends das Essen nicht auf dem Tisch steht. ... Da kann man nur eine Lösung finden indem man vorher anruft und fragt: ,Was gibt's denn? Hast du schon daran gedacht?', man sich selber was macht oder Essen geht."

(I) "I: Was erwarten Sie denn im Hinblick auf die Aufteilung der Hausarbeit ..., wenn das Kind ... da ist? Erwarten Sie ... Verschiebungen, wenn die Frau ... das erste halbe Jahr daheim ist? ...

B: Ich glaube nicht, dass sich da was ändert. A. [Name der Partnerin] muss sich erst an das Kind gewöhnen und an den Umgang mit dem Kind und wird sich vermutlich auch viel darum kümmern schlichtweg."

(m) "Was mir wichtig ist, dass ich weiterhin arbeiten darf. Da hat S. [Name des Partners] den charmanten Vorteil, dass er ... unterhaltspflichtig ist und insofern gar nicht auf die dusslige Idee kommen könnte und sagen könnte 'Süße, ich habe eine tolle ldee. Du bleibst zuhause, ich leiste dir das'.... Was mich davor bewahrt, so die Rolle wie meine Mutter das macht. Meine Mutter musste, sobald ich in die Schule kam, zu Hause bleiben. Da legt mein Vater auch größten Wert darauf. Das war für ihn auch völlig selbstverständlich als ich ihm erzählt habe, dass wir ein Baby kriegen, dass ich dann in Zukunft zu Hause bleibe. ... Wie kommst du denn darauf? Du willst ja wirklich arbeiten.' Ja. Und dann schiebt er das S. in die Schuhe. Ach ja, S. kann das ja nicht. Als ob das negativ wäre. Was für mich ein Vorteil ist. Also das ist mir sehr wichtig." 
(n) "Also, sagen wir mal so, so zum Zeitpunkt der Geburt hat er natürlich deutlich mehr übernommen als ich.... Aber einfach aufgrund der Tatsache, ... ich konnte ja eine Woche lang oder fast gar nicht laufen und danach auch nur ganz wenig. ... Aber danach hat sich das eigentlich alles wieder auf einen normalen Level eingespielt."

(o) "weil wir eigentlich auch beide so von der Einstellung her schon denken, dass man das halt einfach aufteilt und ich mache halt dadurch etwas mehr, weil ich halt nur halb arbeite"

(p) „von sich aus ... den ... Wunsch hatte, wenn ein Kind, dann möchte er sich auch kümmern. ... ja, es war für ihn schon immer dass ... er das eigentlich von sich aus gerne wollte und ... von unserm Rollenverständnis her ist es so, ... dass wir eine gleichberechtigte Vorstellung ... haben"

(q) „die hat jetzt leider, also für uns leider, gekündigt"

(r) "Aber es ist auch oft so, dass, was weiß ich, die Waschmaschine müsste leergeräumt werden oder der Geschirrspüler, willst du's jetzt machen oder willst du aufs Kind aufpassen? Er sagt immer meistens eher, ich will aufs Kind aufpassen."

(s) "für uns war's immer die optimale Regelung: Beide arbeiten und beide betreuen das Kind"

(t) "Ich muss allerdings sagen, wenn mein Mann gesagt hätte, er möchte das nicht ... weiß ich nicht, ob ich ein Kind hätte haben wollen, also die Vorstellung, die ganze Woche mit dem Kind zu Hause und nichts anderes ... wär', glaube ich, nicht ganz so meins." 


\section{Comparative Population Studies}

WWW.comparativepopulationstudies.de

ISSN: 1869-8980 (Print) - 1869-8999 (Internet)

Published by / Herausgegeben von

Prof. Dr. Norbert F. Schneider

Federal Institute for Population Research

D-65180 Wiesbaden / Germany

Managing Editor /

Verantwortlicher Redakteur

Frank Swiaczny

Assistant Managing Editor /

Stellvertretende Redakteurin

Katrin Schiefer

Language \& Copy Editor (English) /

Lektorat \& Übersetzungen (englisch)

Amelie Franke

Copy Editor (German) /

Lektorat (deutsch)

Dr. Evelyn Grünheid

\section{Layout / Satz}

Beatriz Feiler-Fuchs

E-mail:cpos@bib.bund.de

\author{
Scientific Advisory Board / \\ Wissenschaftlicher Beirat \\ Paul Gans (Mannheim) \\ Johannes Huinink (Bremen) \\ Michaela Kreyenfeld (Rostock) \\ Marc Luy (Wien) \\ Clara H. Mulder (Groningen) \\ Notburga Ott (Bochum) \\ Peter Preisendörfer (Mainz) \\ Zsolt Spéder (Budapest)
}

\section{Board of Reviewers / Gutachterbeirat} Martin Abraham (Erlangen)

Laura Bernardi (Lausanne)

Hansjörg Bucher (Bonn)

Claudia Diehl (Konstanz)

Andreas Diekmann (Zürich)

Gabriele Doblhammer-Reiter (Rostock)

E.-Jürgen Flöthmann (Bielefeld)

Alexia Fürnkranz-Prskawetz (Wien)

Beat Fux (Salzburg)

Joshua Goldstein (Berkeley)

Karsten Hank (Köln)

Sonja Haug (Regensburg)

Aart C. Liefbroer (Den Haag)

Kurt Lüscher (Konstanz)

Dimiter Philipov (Wien)

Tomáš Sobotka (Wien)

Heike Trappe (Rostock) 